\title{
A SOBERANIA IDIOMÁTICA NA AMÉRICA LATINA: CONTEXTOS DE RESISTÊNCIA
}

\author{
SOBERANIAA IDIOMÁTICA EN AMÉRICA LATINA: CONTEXTOS DE RESISTENCIA
}

\author{
João Colares da Mota Neto ${ }^{1}$ \\ Gabriela Costa Faval ${ }^{2}$
}

\begin{abstract}
RESUMO: Os processos de colonização de Espanha e Portugal foram marcados pela imposição linguística feita sobre suas colônias nas Américas, ocasionando a perda de identidade por parte dos povos originários locais e a subordinação linguística que perdura nos tempos atuais. Este artigo objetiva debater as resistências e movimentos, como o Manifesto pela Soberania Idiomática de 2005 - que foi oposição contundente às imposições idiomáticas promovidas pela Real Academia Espanhola (RAE) - e os posicionamentos independentistas do idioma no Brasil, no início do século XIX e o mais recente Acordo Ortográfico de 1990, assinado pelos países falantes da língua portuguesa. Por meio de um estudo bibliográfico e considerando-se o aporte teórico de Walsh (2009) e Brandão (2009), o conceito de colonialidade idiomática em Lagares (2013) e Parera (2014) e da historicização do português no Brasil em Garcia (2007), Guimarães (2005) e Medeiros (2006), buscou-se enfatizar os aspectos culturais, identitários e políticos da implantação dessas línguas, as lutas travadas no intuito de garantir a soberania idiomática dos países marcados pela colonização e denunciar as perspectivas colonialistas e centralistas, ainda presentes e impostas na América Latina. Concluiu-se ser imprescindível a reafirmação das muitas identidades idiomáticas e a ruptura com as imposições linguísticas de matriz europeia, de modo a possibilitar o reconhecimento e a visibilidade étnico-cultural e identitária dos povos que constituem o espanhol latino-americano, o português brasileiro e suas diversidades.
\end{abstract}

Palavras-chave: Colonialidade linguística; soberania idiomática; decolonialidade; linguagem.

RESUMEN: Los procesos de colonización de España y Portugal estuvieron marcados por la imposición lingüística que se hizo a sus colonias en las Américas, lo que provocó la pérdida de identidad de los pueblos originarios locales y la subordinación lingüística que persiste en la actualidad. Este artículo tiene como objetivo discutir las resistencias y movimientos, como el Manifiesto por la Soberanía Idiomática de 2005 - que fue una fuerte oposición a las imposiciones idiomáticas promovidas por la Real Academia Española (RAE) - y las posiciones independentistas de la lengua en Brasil a principios del siglo XIX y el más reciente Acuerdo Ortográfico de 1990, firmado por los países de habla portuguesa. A través de un estudio bibliográfico y considerando la contribución teórica de Walsh (2009) y Brandão (2009), el concepto de colonialidad idiomática en Lagares (2013) y Parera (2014) y la historización del portugués en Brasil en García (2007), Guimarães (2005) y Medeiros (2006), se buscó destacar los aspectos culturales, identitarios y políticos de la implantación de estas lenguas, las luchas para garantizar la soberanía

\footnotetext{
${ }^{1}$ Professor do Programa de Pós-Graduação em Educação da Universidade do Estado do Pará-UEPA. Doutor em Educação pela Universidade Federal do Pará-UEPA, com Doutorado Sanduíche na Universidad Pedagógica Nacional de Colombia. Coordenador da Rede de Pesquisa sobre Pedagogias Decoloniais na Amazônia. Coordenador adjunto da Cátedra Paulo Freire da Amazônia. Integrante da coordenação brasileira do Conselho de Educação Popular da América Latina e do Caribe.

${ }^{2}$ Mestranda em Educação, linha "Saberes culturais e educação na Amazônia” pela Universidade do Estado do ParáUEPA. Especialista em Educação e Cultura: confluências, pela Universidade Federal do Pará-UFPA.
} 
idiomática de los países marcados por la colonización, y denunciar las perspectivas colonialistas y centralistas aún presentes e impuestas en América Latina. Se concluyó que es esencial reafirmar las múltiples identidades idiomáticas y la ruptura con las imposiciones lingüísticas de la matriz europea, para hacer posible el reconocimiento y la visibilidad e identidad étnico-cultural de los pueblos que conforman el español latinoamericano, el portugués brasileño y sus diversidades.

Palabras clave: Colonialidad lingüística; soberanía idiomática; decolonialidad; lenguaje.

\section{Introdução}

Em 1771, um decreto espanhol tornava proibido o ensino e a divulgação das línguas précolombianas, como o quéchua, em suas colônias americanas. Cátedras e academias destinadas ao estudo dessas línguas foram fechadas e, inclusive, o uso delas em público também foi proibido. O objetivo era impor e garantir a disseminação do castelhano (língua oficial dos colonizadores das Américas) nas terras de além mar; porém, esta imposição só começou a ser alcançada com a emancipação da metrópole e o uso, pela Espanha, de administradores da elite local (hispano-americanos), que impuseram o idioma nos planos de colonização, como elemento de nacionalização e controle social (SANZ, 2011).

Apesar dos seus esforços, a Espanha encontrou, a partir do século XIX, elementos de oposição: por um lado, a extrema precariedade do sistema escolar espanhol - que enfraquecia a imposição do espanhol de Madri dentro da própria Espanha, em disputa constante com o castelhano e o catalão - e, por outro, a emergência dos regionalismos e nacionalismos periféricos que questionavam o império espanhol.

Entre 1840 e 1894 a Espanha perde, gradativamente, os territórios coloniais da América. Seis anos depois a burguesia comercial espanhola inicia uma ofensiva americanista, cujo objetivo era o fortalecimento do comércio das Américas a partir da difusão ampla da ideia do território "ibero-americano", que mostrasse ao mundo uma união transoceânica entre Espanha e suas extintas colônias e o fortalecimento do nacionalismo espanhol, mediante a criação da "União Ibero-americana”, uma associação de caráter oficialista e grêmio-patronal que, como afirma Sanz (2011), permaneceu ativa até o fim da guerra civil, "sob a ideia de que Ibero-américa era o mercado natural da Espanha”. Ainda segundo a autora:

se propuso desde sus inicios «estrechar relaciones sociales, económicas, científicas, literarias y artísticas de España, Portugal y las naciones americanas donde se habla el español y el portugués, y preparar la más estrecha unión comercial en el porvenir». (SANZ, 2011, p. 152)

A ideologização da consciência americanista promovida pela União Ibero-americana tinha entre suas estratégias fundamentais o fortalecimento de uma identidade hispanoamericana e o desenvolvimento de uma série de programas culturais americanistas que se fundavam em quatro elementos: a raça, a história, religião e o idioma e que se complementava com a negação dos elementos alternativos de outras comunidades. Desses quatro elementos, o idioma era o ponto chave para a manutenção da soberania espanhola nas Américas, por possuir valores psicológicos, integradores e identificadores que tinham por função principal a 
homogeneidade da comunidade espanhola mundial.

Da primeira metade do século XIX em diante, os defensores do pensamento de emancipação levantam como questionamento a obrigatoriedade de, tendo se tornado independentes, permanecerem subordinados idiomaticamente e a Espanha ser a detentora da língua. Esse americanismo crescente e fortalecido pelos ideais de emancipação americanos, tornaram a língua o mais importante elemento de ideologização política dentro das Américas.

No Brasil, a implantação do português como idioma oficial teve algumas similaridades com a do espanhol. A partir de 1532 (quando se inicia oficialmente a ocupação colonialista) ele sofre inicialmente três afastamentos em relação ao português europeu (GUIMARÃES, 2005). Antes disso, no país usavam-se duas línguas gerais ${ }^{3}$ : a língua geral paulista, usada no movimento de expansão bandeirante e o nheengatu, usado no movimento de ocupação da Amazônia e que ainda é usado por algumas etnias indígenas na atualidade.

O primeiro afastamento se deu logo após a ocupação, em 1500, com o uso do tupi (mais precisamente o tupinambá) como língua oficial da colônia ao lado do português, graças à influência jesuítica. Isso durou até 1757, quando uma Provisão Real (MEDEIROS, 2006) proibiu a utilização do tupi e concretizou a substituição desta pelo português. Tal medida se torna possível graças à chegada de uma grande quantidade de imigrantes da metrópole que proporcionaram a suplantação do tupi. Dois anos depois, em 1759, com a expulsão dos jesuítas, o português se oficializa como única língua da colônia, mas guardou heranças das línguas indígenas em sua estrutura.

A chegada dos africanos escravizados propiciou o segundo afastamento e resultou em uma nova alteração linguística no português do Brasil devido à introdução de palavras originárias do iorubá nigeriano e do quimbundo angolano. E o terceiro afastamento ocorreu no século XVIII, quando a língua é reformulada em Portugal, sofrendo algumas alterações que não foram acompanhadas pelo Brasil, que se manteve fiel à pronúncia e às características do português colonial.

Entre 1801 e 1821, a transferência da família Real portuguesa para o Brasil proporcionou um reaportuguesamento intenso da língua devido à quantidade de portugueses que acompanharam a Corte, mas isto só teve peso nas grandes cidades. Após 1822, com a independência brasileira concretizada e o aumento do fluxo migratório, principalmente no sul do país, o português europeu e o brasileiro se distanciam novamente de forma mais enfática, gerando diferentes modalidades de pronúncia e lexicais entre as regiões.

Os avanços tecnológicos do século XX culminaram nesse afastamento. O Brasil passa a incorporar palavras que não foram assimiladas por Portugal e, inclusive, determinar diferenças de escrita. $\mathrm{O}$ nacionalismo e o individualismo que caracterizaram o movimento romântico no início do século deram surgimento a uma literatura nacional que foi fortificada em 1922 pelo movimento modernista e que defendia a necessidade de romper com o modelo português e privilegiar as peculiaridades brasileiras.

Vale ressaltar que o português que foi trazido às Américas com as grandes navegações era resultante de uma sucessão de misturas ocasionadas pelas guerras e invasões ocorridas na

\footnotetext{
${ }^{3}$ Língua de base indígena praticada amplamente no território nacional.
} 
Península Ibérica entre os séculos I a.C e VIII d.C., e que causaram várias diferenciações sobre o latim usado pelos romanos. A modificação que originou a língua portuguesa se deu na retomada da Península Ibérica pelos cristãos, após o ano 711 d.C., por ocasião da invasão muçulmana, dando surgimento ao galego-português. Paralelamente a isto surge o Condado Portugalense, subordinado aos reinos de Castela e Leão, reconhecido como país independente em 1128, na Batalha de São Mamede, quando então assume o nome de Portugal.

Esse português falado em Portugal tampouco era homogêneo. Ele convivia com divisões de dialetos internos que possuíam características próprias culturais e de fala. Assim, a chegada de mais colonizadores após 1808 ocasionou o convívio de divisões do português em um mesmo espaço/tempo brasileiro (GUIMARÃES, 2005).

Começam, assim, diversas medidas da Coroa Portuguesa para garantir o fortalecimento do português como língua oficial nas terras brasileiras e, seguindo o exemplo da Espanha, passa a proibir as línguas locais indígenas e gerais.

\section{De Pombal à criação da RAE: a destruição gradativa das línguas originárias}

Em 1757 as lutas territoriais entre Portugal e Espanha começam a ser intensificadas. Uma das principais medidas do período pombalino é, então, implantada quando D. José I promulga a lei intitulada Diretório dos Índios, elaborada e executada no Brasil pelo Marquês de Pombal, que elevava todos os aldeamentos indígenas da colônia à condição de vilas ou aldeias, colocando-as sob a administração de um diretor.

O Diretório assegurava liberdade aos índios e educação individualizada para meninos e meninas, porém, proibia o uso da língua geral (tupi) e de outro idioma que não fosse o português, proibia também a nudez (costume da cultura indígena), as habitações coletivas e exigia a adoção de um sobrenome português pelos indígenas, - forma de comprovar que o território estava ocupado por portugueses legítimos - punindo com a morte os que desacatassem essas determinações.

A mestiçagem passou a ser estimulada, também, a partir da promulgação dessa lei, visto que o objetivo principal dela era a completa integração dos índios à sociedade colonial, idealizando um futuro de homogeneização racial onde brancos e índios não pudessem mais ser diferenciados com base em nenhum critério (GARCIA, 2007). Para Garcia (2007), a extinção das diferenças existentes entre colonos e indígenas abrangia três aspectos que envolviam a língua. A autora afirma que:

No Diretório há um parágrafo dedicado especificamente ao tema, no qual a imposição da autoridade do colonizador aparece como derivada da implantação do seu idioma às populações "conquistadas". Neste parágrafo, foram desenvolvidas e articuladas três principais ideias sobre o tema. Primeiramente, a percepção de acordo com a qual o uso do idioma nativo estava relacionado aos costumes tribais, em que um reforçava o outro. Em segundo, que a adoção do idioma civilizado redundaria na civilização dos costumes. Em terceiro, que a imposição da "língua do príncipe" acarretaria a sujeição dos povos conquistados. (GARCIA, 2007, p. 25) 
Tanto as línguas indígenas quanto as africanas, provenientes da chegada dos negros escravizados, representavam entraves significativos para os propósitos de expansão linguística de Portugal e Espanha, (apesar de nunca ter havido, no Brasil, uma língua geral de base africana), porém, a diversidade linguística e o uso das línguas pertencentes a esses dois grupos nas colônias, significava uma forte concorrência para a hegemonia do português e do espanhol europeus.

Enquanto a Espanha buscou colonizar mediante o uso da força e a dizimação de muitos povos, Portugal optou pela integração dos índios à sociedade colonial brasileira como estratégia para a ocupação de suas terras, impedindo o avanço da Espanha, com quem disputava territórios em virtude do uti possidetis ${ }^{4}$ do Tratado de Madri (GARCIA, 2007, p.27 - grifo da autora). Os índios, assim, seriam transformados em colonos, vassalos da Coroa que contribuiriam para confirmar o direito à ocupação portuguesa.

Essa integração, no entanto, requeria "transformar o estatuto jurídico e social que os índios tinham na sociedade de Antigo Regime" (GARCIA, 2007), que versava sobre a pureza racial concebida a partir da noção de raça como combinação entre ancestralidade e crença religiosa. A colonização acrescentou a esses critérios o fenótipo, estabelecendo o lugar do indivíduo na sociedade a partir de sua cor. Ainda segundo a autora:

Ao tentar erradicar as especificidades dos diferentes grupos indígenas, Sebastião José de Carvalho e Melo ${ }^{5}$ buscava, por meio do Diretório, criar uma homogeneidade entre os seus súditos, na qual o compartilhamento do mesmo idioma tinha um papel fundamental. No entanto, este projeto encontrou resistência tanto por parte dos colonos como dos índios. Ao voltar-se contra as línguas indígenas e pôr em prática uma política agressiva contra estas, acabou por transformá-las [...] num elemento definidor da identidade da população indígena estabelecida na fronteira meridional da América portuguesa. (GARCIA, 2007, p.28).

A Lei durou até 1798, quando foi revogada e os índios aldeados foram "emancipados"; porém, tanto pela quantidade de portugueses chegados junto com a família real quanto pelas consequências da implantação do Diretório dos Índios e pela criação da imprensa brasileira (que reforçou o uso da língua oficial), o português já se encontrava disseminado e a língua geral praticamente extinta nesse então.

Tanto Portugal quanto Espanha objetivavam, em seus processos de colonização, a disseminação homogênea de suas línguas a nível mundial e o fortalecimento delas em suas colônias, e criaram estratégias para atender esses propósitos. No entanto, para o Brasil, a língua nunca adquiriu aspectos que evidenciassem essa homogeneidade, principalmente porque o próprio português europeu não era homogêneo em sua origem.

Seguindo esses mesmos interesses, em 1713 a Espanha dá surgimento à RAE (Real Academia Espanhola), criada pelo Marquês de Villena e que também trazia consigo a ideia de "pureza" da língua e objetivava reforçar a padronização hegemônica de que a Espanha precisava

\footnotetext{
${ }^{4} \mathrm{O}$ princípio de uti possidetis previa que na demarcação dos limites territoriais, caberia a cada Coroa ibérica as terras por ela efetivamente ocupadas.

${ }^{5}$ Marquês de Pombal.
} 
para garantir sua força política, econômica e territorial. A RAE inferiorizava e desprezava as variações linguísticas surgidas nos países colônias e reforçava o "valor de origem" do espanhol europeu. Isto fica evidente após a criação de entidades como o Instituto Cervantes e as Academias subordinadas a ele e, por fim, em 2005, do Diccionario Panhispánico de Dudas.

Em referência a essas instituições, Lagares (2013) afirma que através delas, a RAE exercia, mediante imposição linguística, a perpetuação do controle colonial, reforçada pelo Instituto Cervantes (IC), com base em uma "política de diversidade piramidal", na qual um núcleo linguístico tem mais peso que outros e que acaba por direcionar (mediante padrões eurocêntricos) o ensino da língua espanhola em todo o mundo.

Para Oliveira:

A imposição da norma espanhola sobre a americana, impregnada de nuanças sócio-históricas, constrói-se sob paradigmas antigos de "correção" e "limpeza" do idioma [...] Isso significa que à força da imposição de uma norma, corroborada por uma pequena parte da população (elite), despreza-se o estabelecido pela maioria dos falantes daquela determinada comunidade linguística (OLIVEIRA, 2014, p. 22).

Desta forma, as línguas pertencentes aos povos originários passam a ser atacadas direta e drasticamente, objetivando sua completa substituição pelas línguas colonialistas, projeto que foi amplamente apoiado pelas elites locais, mas que não significava, contudo, uma ruptura na hierarquização étnica da sociedade colonial e que, no Brasil, não obteve os resultados desejados.

Mesmo objetivando essa homogeneidade linguística e estabelecendo critérios de igualdade entre colonos e indígenas, o português implantado pelo Diretório de Pombal não deixou de ter características piramidais na sociedade colonial, onde estavam pré-estabelecidos os lugares ocupados pelos sujeitos sociais. Pelo decreto, os índios não podiam mais ser chamados de "negros da terra" (GARCIA, 2007, p. 25), mas ainda eram vistos como inferiores e primitivos.

A língua portuguesa era a língua da Coroa, sendo falada por todos os seus representantes diretos e indiretos, já o guarani e as línguas africanas (que nunca chegaram a ser línguas gerais), não deixaram de ser considerados dialetos primitivos e, por isto, era compreensível e justificável sua proibição nos territórios das colônias, tendo sido determinadas duras sanções aos infratores.

Aproximadamente 3 mil guaranis adentraram às terras brasileiras atraídos pela Lei do Diretório dos Índios, mas se viram obrigados a abrir mão de suas identidades ao não poderem fazer uso de sua língua. As crianças que adentraram às escolas indígenas estavam entre os 6 e os 12 anos (GARCIA, 2007), idade em que já possuíam o domínio da língua guarani. Uma vez por semana eram autorizadas a receber a visita de seus pais, mas era proibida a comunicação em outra língua que não fosse o português, estando todos sujeitos a castigos severos e a fiscalizações permanentes. Porém, quando havia feriados, as crianças visitavam os parentes e, logicamente, exercitavam sua comunicação na língua de origem, já que os índios mais velhos se recusavam a aprender o português. Esta foi, sem dúvida, uma das causas do fracasso dos aldeamentos como instrumentos de disseminação do português, visto que, apesar de as escolas indígenas terem funcionado por mais de duas décadas, a quantidade de indígenas interessados em aprender a 
língua foi diminuindo gradativamente até ser considerada insuficiente e o abandono total do idioma guarani nunca chegou a concretizar-se.

É inegável a resistência indígena em abrir mão de suas práticas, vestimentas e, principalmente, da língua, o que gerou constantes reclamações por parte dos colonos e administradores. As relações estabelecidas entre ambos lados eram sempre de barganhas e acordos, tendo os indígenas sabido fazer muito bom uso da necessidade que Portugal tinha dos aldeamentos para garantirem sua autonomia.

Burke (1995 apud GARCIA, 2007) levanta a possibilidade de que a tentativa de exclusão das línguas nativas promovida pelo Diretório tenha despertado nos índios a percepção de sua relevância identitária já que, para ele, os "signos ou emblemas de identidade só se tornam signos quando outra pessoa tenta eliminá-los” (p. 38). Assim mesmo, o guarani acaba sofrendo muitas modificações estruturais a partir da experiência nos aldeamentos portugueses.

\section{A língua como instrumento de luta: reivindicações de identidade e soberania}

A luta guarani pela manutenção de sua língua pode ser considerada a primeira resistência efetiva às imposições hegemônicas portuguesas e, mesmo não sendo mais uma língua pura, em virtude dos contatos anteriores com portugueses e espanhóis (GARCIA, 2007), era a língua resultante da experiência nas missões, tendo se tornado parte da história e da vida dos guaranis, daí sua relevância para a etnia. A proibição de uso deu aos indígenas a percepção da diferenciação que havia entre brancos e índios e tornou a língua um "agente de construção e permanência das fronteiras étnicas”, como afirma Garcia (2007, p. 38), contribuindo para um fortalecimento identitário a partir da conscientização das especificidades linguísticas. Mesmo assim, o português se torna a língua oficial da colônia portuguesa, principalmente após a transferência da família Real, mas não foi a única língua falada no território colonial, como já destacado.

O contato com as línguas indígenas, a chegada de africanos escravizados pela colonização - que possuíam línguas e dialetos diferentes entre si - a própria transferência da Família Real portuguesa para o Brasil, cuja corte trazia integrantes de regiões distintas de Portugal com especificidades linguísticas e, por fim, a intensa imigração europeia ocorrida após o fim da escravidão, proporcionaram ao português brasileiro características próprias de fala e escrita e, a partir dessa compreensão, o surgimento de um movimento de nacionalização da língua brasileira.

Em 1823, as discussões em torno da autonomia linguística e o legado de Portugal estavam acirradas:

De um lado, o Visconde de Pedra Branca, Varnhagen, Paranhos da Silva e os românticos como Gonçalves Dias, José de Alencar alinhavam-se entre os que defendiam nossa autonomia propugnando por uma língua nossa, a língua brasileira. De outro, os gramáticos e eruditos consideravam que só podíamos falar uma língua, a língua portuguesa, sendo o resto apenas brasileirismos, tupinismos, escolhos ao lado da língua verdadeira (ORLANDI, 2005, p. 29).

O embate propiciou que em 1826 o deputado José Clemente Pereira propusesse ao 
parlamento a redação dos diplomas dos médicos cirurgiões na "língua brasileira", por considerála mais adequada. Essa proposta reforçou os discursos pela autonomia idiomática e impulsionou o termo "língua nacional" (ORLANDI, 2005), adotado em 1930 pela Câmara do Distrito Federal. A decisão definitiva pela opção da língua portuguesa só foi retomada com a Constituição de 1946, mas não finalizada. Para Orlandi (2005, p. 29):

Isso quer dizer que até hoje não decidimos se falamos português ou brasileiro.
Embora a cultura escolar se queira, muitas vezes, esclarecedora em sua
racionalidade e moderna em sua abertura, acaba sempre se curvando à
legitimidade da língua portuguesa que herdamos e, segundo dizem, adaptamos
às nossas conveniências, mas que permanece em sua forma dominante
inalterada, intocada: a língua portuguesa. E quem não a fala, ainda que esteja
no Brasil, que seja brasileiro, erra, é um malfalante, um marginal da língua. É,
pois, impressionante como a ideologia da língua pura, a verdadeira, faz manter
o imaginário da língua portuguesa.

O que atesta, então, nossa materialidade linguístico-histórica é que estamos diante de duas línguas distintas no léxico, em contornos sintáticos, pronúncias e historicidade. Estamos, como afirma Orlandi (2005), diante de línguas que são tidas como iguais (caso tanto do português quanto do espanhol) onde “o 'mesmo' abriga, no entanto, um 'outro', um diferente histórico que o constitui" (p. 30) e cuja homogeneidade linguística é apenas um reflexo da colonialidade histórica.

Todo processo de colonização envolve aspectos culturais. A supremacia de um povo/nação sobre outros/as implica não apenas na dominação e subjugação populacional, política e econômica, mas requer, também, o silenciamento, a invisibilização e, em muitos casos, até a destruição parcial ou total da cultura local. A implantação do espanhol e do português como idiomas oficiais e/ou secundários na América Latina está diretamente relacionada a processos históricos de dominação, exclusão e invisibilização cultural.

Para Lagares:

O próprio caráter social e cultural do objeto "língua" (que, como todo objeto cultural, tem uma história) faz com que seja impossivel reconhecer e delimitar idiomas sem levarmos em conta as condições sociopolíticas e históricas das comunidades que os falam. (LAGARES, 2013, p. 386).

A linguagem de um povo, nação ou grupo social é o meio que estes utilizam para estabelecer relações internas e externas. Mas, como afirma Lagares (2013), não é um elemento isolado da história e da cultura dos que a utilizam. A linguagem é um objeto cultural e, assim como a cultura, modificável ao longo do tempo. Isso pressupõe a existência de culturas e, consequentemente, de linguagens silenciadas dentro do processo de ocupação territorial, ou ainda, como nos casos de Portugal e Espanha, uma constante ação de hegemonia e padronização da língua em relação à América.

Tal prática, que Walsh (2009, p. 14-15) cita como a "colonialidade do poder", a partir dos conceitos criados por Aníbal Quijano $(2005)^{6}$, surge a partir da hierarquização racial que

\footnotetext{
${ }^{6}$ QUiJANO, Aníbal. Colonialidade do Poder, Eurocentrismo e América Latina. In: LANDER, Edgardo (Org.) A
} 
coloca os brancos (europeus) em um patamar superior aos "índios" e "negros" (regionais), e a quem identifica como "identidades comuns e negativas", apagando suas diferenças históricas, culturais e linguísticas. A autora cita ainda a "colonialidade do saber", em que os aspectos culturais, religiosos, práticas sociais e tradições dos povos originários são categorizados como "primitivos" ou "bárbaros" e, portanto, negados como culturas passíveis de aceitação. Esses e outros elementos são vistos por Walsh como uma "(re) colonialidade" que se mantêm presente ainda na atualidade e que é reforçada por instituições reguladoras.

Parera (2014) usa o termo "neocolonização" para fazer referência a essa retomada sutil de velhos interesses e intenções por parte das ex-metrópoles da América Latina e reforça seu conceito afirmando que a segunda colonização começa a ser desvendada, mas encontra-se encoberta pelo "manto" da ideologia neoliberal.

Hoy vivimos una época de nuestra historia que parece calcada de esa trágica experiencia, nuevamente hemos sido colonizados, sólo que ahora los pizarros, almagros, de sotos, son los gerentes de entidades bancarias, empresas eléctricas, aseguradoras, empresas de hidrocarburos, la tristemente célebre Telefónica y otras transnacionales españolas. Por supuesto, también hay la parte "cultural" de la neocolonización y para eso están presentes en nuestro país la Real Academia Española, el Instituto Cervantes, la editorial Santillana y otras entidades menos visibles (PARERA, 2014, s/p).

A consolidação do processo colonizador, segundo a autora, se dá em consonância com uma colonização linguística, impulsionado por elites locais que reforçam o conceito de "pátria mãe" ao referir-se à Espanha e Portugal e que, não podendo utilizar-se do termo neocolonialismo, já que este não permite identificar língua e nação, usam-se da terminologia "pan-hispanismo", no caso do espanhol.

Em concordância com a colonialidade do saber, mencionado por Walsh, Parera descreve a primeira etapa do colonialismo linguístico a partir de algumas características:

- $\quad$ Falas e escritos pejorativos, por parte dos colonizadores, sobre as línguas;

- Apropriação dos invasores da escrita e da fala dessas línguas;

- Transformação de aspectos linguísticos indígenas em católicos (isto descaracterizou a linguagem originária e criou uma terceira língua no processo, homogeneizando a comunicação e facilitando a implantação do castelhano);

- A imposição da língua matriz em todos os espaços da colônia.

Esta última característica apresenta, ainda, aspectos da colonialidade do saber, por pressupor o eurocentrismo como perspectiva hegemônica. Isso "evidencia que a diferença construída e imposta desde a colônia”, como comenta Walsh, "afirma o lugar da raça, do racismo e da racialização” para concretizar a dominação e conclui seu pensamento, em concordância com Parera, ao afirmar que:

colonialidade do saber: eurocentrismo e ciências sociais. Perspectivas latino-americanas. Buenos Aires: CLACSO, 2005. 
Enquanto a dupla modernidade-colonialidade historicamente funcionou a partir de padrões de poder fundados na exclusão, negação e subordinação e controle dentro do sistema/mundo capitalista, hoje se esconde por trás de um discurso (neo)liberal multiculturalista. Desse modo, faz pensar que com o reconhecimento da diversidade e a promoção de sua inclusão, o projeto hegemônico de antes está dissolvido. No entanto, mais que desvanecer-se, a colonialidade do poder nos últimos anos esteve em pleno processo de reacomodação dentro dos desígnios globais ligados a projetos de neoliberalização e das necessidades do mercado; eis aí a "recolonialidade" (WALSH, 2009, p. 16).

Através de diversos dicionários de normas e gramática, instituições como a RAE, a Academia de Ciência de Lisboa e a Academia Brasileira de Letras impõem e/ou ajudam a impor as superioridades das línguas consideradas por elas "puras" (grifo nosso) ao mundo e reafirmam o que autores como Walsh e Lagares identificam e chamam de recolonização, amparada por uma ideologia crescente de globalização e neoliberalismo. Esses documentos passam, assim, a reger as instituições educativas do mundo inteiro, as regras e normas do ensino das línguas europeias, sempre com características hegemônicas e de uma universalização eurocêntrica da língua. $\mathrm{O}$ alcance desses dicionários não é popular, visto que o objetivo das grandes corporações não é o aperfeiçoamento da língua, mas sim o exercício da dominação das classes dominadas.

Vasquez (2008 apud OLIVEIRA, 2014, p. 43) trata ideias como a de uma língua panhispânica ou da homogeneidade linguística de utópicas, tendo-se em conta, por exemplo, que tanto o português quanto o espanhol "ganharam identidade própria" em cada país onde foram impostos e define tal questão como político-identitária, além da linguística. Já o português do Brasil, além disso, apresenta uma diferença interna que está diretamente relacionada à historicidade de ocupação dos territórios regionais, fato que lhe concedeu materialidades discursivas e efeitos de sentidos diferenciados que marcam sua singularidade linguística.

Foi em um contexto semelhante a esse que a RAE elaborou o Dicionário Panhispânico de Dúvidas (DPD), cujo objetivo era não apenas sanar dúvidas a respeito da pronúncia ou escrita de uma palavra, como também reforçar o conceito de língua standard, já que a divisão estabelecida pelo documento (Espanha x América x Estados Unidos) revela a interposição europeia às Américas.

O DPD, ao mesmo tempo que reconhece a autoridade das demais academias linguísticas, requer para si como única autoridade válida, a legitimidade para resolver questões inerentes ao idioma. Além disso, a RAE estabelece poderes de elaboração e reformulação da regra linguística aos falantes "cultos" de cada país, ou seja, a uma elite cultural, relegando às academias o papel de divulgadoras das normas. Mas, para além da divergência textual em relação às 22 academias que elaboraram o DPD junto à RAE, e tendo em conta a colonização dos povos originários das Américas, podemos concluir, sem dúvida alguma, que essas normas não fazem alusão às palavras e expressões usadas pelos povos ameríndios e seus descendentes ao fazerem uso da língua, visto que estes não pertencem às chamadas "elites cultas". Vale lembrar que 70\% das palavras identificadas no DPD como "erros" e que não são "recomendadas" pela RAE estão relacionadas às línguas pré-colombianas. 
Envolta em muitas contradições, a relação entre o DPD e os documentos normativos, disponibilizados pela RAE, tornam inevitável a compreensão de que a proposta de panhispanismo tenta ser apresentada com uma "roupagem" diferente, mas, no fundo, está apenas remodelando a normatividade e, portanto, seus aspectos colonialistas.

Os primeiros dicionários produzidos no Brasil caracterizavam-se pelo bilinguismo português-tupi, reforçando a existência de uma "língua brasileira" repleta de "brasileirismos" (ECHEVARRIA; STURZA, 2015, s/p). A língua, segundo Sturza (2015), começava a reivindicar um status identitário enquanto português brasileiro que buscava, em um princípio, a instrumentalização dos idiomas nativos, visando a praticidade e a religiosidade, ou seja, era um instrumento de colonização. Porém, após o estabelecimento de uma gramática própria, o país ganha autonomia gramatical e as produções nacionais passam a ser mais procuradas que os dicionários fornecidos por Portugal.

É preciso ressaltar que a implantação do português no Brasil sempre esteve atrelada a imposições e ao uso da força, seja no período colonial ou anos depois, durante o Estado Novo, quando foi imposta violentamente aos imigrantes. Como afirma Palhares (2012), a colonização do Brasil foi, também, uma colonização através do simbólico e do cognitivo, que "se manteve viva mediante o currículo escolar, a cultura e das mais diversas formas de ser e estar na sociedade moderna” (p. 4) e cujas imposições sistemáticas deixaram marcas profundas na identidade brasileira.

Por esse motivo, Barthes (1978) afirma que a língua é fascista, pois assume um caráter de obrigatoriedade quando associada a contextos de dominação, ou seja, é uma das principais armas de subjugação de um povo por outro e atua sempre a serviço de um poder estabelecido.

O sentimento de nacionalismo que atingiu a o Brasil durante o Romantismo fez com que instituições como o Colégio Pedro II, no Rio de Janeiro, se tornassem referência em estudos relacionados à língua nacional (PASSINATTO, 2018). Obras como Luciola, O Gaúcho, Senhora, O Guarani e Iracema, de José de Alencar, também serviram aos propósitos nacionalistas da língua. Junto às gramáticas publicadas, essas obras desempenharam importante papel na afirmação da identidade brasileira, como afirma Passinatto (2018), apresentando a utilização de neologismos que foram duramente criticados por gramáticos lusitanos, mas que representavam um modo de falar próprio do povo brasileiro.

As diversas tentativas de unificação da língua entre Portugal e Brasil, ocorridas após 1911, quando Portugal fez sua primeira reforma (que não foi extensiva ao Brasil) caminhavam para a construção de documentos que idealizavam uma equiparação sempre em favorecimento à pronúncia e gramática do português europeu e em detrimento da diversidade linguística brasileira. Talvez por este motivo as tentativas de acordo ortográfico que foram propostas tenham fracassado. Era evidente, tanto do lado de cá quanto do lado de lá do oceano, que quem sentava à mesa de negociações não estava a falar a mesma língua.

\section{A soberania idiomática nos discursos decoloniais - "La Segunda Independencia"}

Se temos posta, então, uma segunda colonização a partir da língua, nada mais natural que haver, ao longo do processo, uma segunda luta por independência. Assim sendo, em 
setembro de 2013, a reivindicação da visibilidade negada aos dialetos e línguas pré-colombianas que constituem o espanhol das Américas, era iniciada através do "Manifesto por una soberania idiomática", publicado no jornal eletrônico "Página 12", da Argentina. Nele, intelectuais latinos, escritores e acadêmicos defendiam a necessidade de surgimento de uma corrente de ação latino-americana que propusesse a soberania linguística do espanhol das Américas. Ao mesmo tempo, o documento denunciava o "espírito centralista" da Real Academia Espanhola (RAE) e do Instituto Cervantes e afirmava:

Las instituciones de la lengua son globalizadoras cuando piensan el mercado y monárquicas cuando tratan la norma. La noción pluricéntrica, entendida en sentido estricto (diversos centros no sometidos a autoridad hegemónica), queda cabalmente desmentida entre otros ejemplos por el Diccionario Panhispánico de Dudas (2005), en el que el 70 por ciento de los "errores" que se sancionan corresponde a usos americanos (MANIFESTO, 2013, p. 86 - I).

A relevância desse documento vem, principalmente, da crítica à tentativa espanhola de apagar as diferenças internas, negando a heterogeneidade étnica e cultural dos povos tradicionais latino-americanos. Um pouco antes, em 2005, Fernando Lázaro Carreter, então presidente do recentemente criado Instituto Cervantes, afirmava, ao ser questionado sobre qual seria sua relação com a RAE:

A RAE tem como objetivo primordial promover e defender a unidade de uma língua [...], o faz naturalizando a norma que o consenso geral vai estabelecendo [...] essa é a língua, única e diversa, cujo ensino se difunde [...] dentro de um plano de expansão formidável (Instituto Cervantes, Opinión, sep./oct. de 2005, p.5)

Essa fala que unificava as ações da Real Academia Espanhola e do Instituto Cervantes em torno da homogeneização da língua espanhola, deixava claro que o uso da ideia de "diversidade linguística" não dizia respeito às características americanas da língua e que, mesmo tentando aparentar outra política, tanto a RAE quanto o Instituto Cervantes representavam o poder espanhol sobre as Américas.

Por uma enormidade de pressões, a RAE se viu obrigada, ao longo dos anos, a modificar discursos, passando a defender - pelo menos no papel - a "desnacionalização da língua espanhola". Tanto em documentos oficiais quanto no slogan, a RAE passou a tentar convencer o mundo de que a língua não era mais espanhola, mas universal, envolvendo falantes nativos de todas as partes. Porém, desnacionalizar o espanhol, no entendimento da RAE, significava, ainda, expandir o idioma a todas as partes e não torná-lo diverso e plural, visto que todos os documentos e textos publicados na página oficial da entidade colocavam (e ainda colocam), lado a lado, a ideia de desnacionalização e a de unificação linguística, bastante antagônicas entre si, se pensarmos que não se pode unificar uma língua que ultrapassou todas as fronteiras.

Em 2017 a revista chilena "La Marraqueta" se soma ao embate publicando a reportagem do estudante de letras hispânicas, Jorge Ortiz, intitulada "El invisible colonialismo de la lengua”, em que entrevista o linguista norte-americano e pesquisador do departamento de Ciências da Linguagem da Universidade Católica do Chile, Scott Sadowsky, que afirmou 
enfaticamente: "no mundo hispano-falante vivemos um colonialismo brando" (p.2) e completa:

La primerísima institución española de colonización blanda es la Real Academia Española (RAE), la cual sigue viva y pujante entrometiéndose en la soberanía lingüística de centenares de millones de americanos y sus intromisiones son aceptadas sumisamente por hablantes y estudiosos por igual (SADOWSKY apud ORTIZ, 2017, p. 2-3).

Como exemplo, o linguista cita na reportagem um dos decretos mais recentes da RAE a respeito da mudança de nome das letras "b", "v", “w” e "i”, que ignorou a nomenclatura centenária dessas letras nos países latinos e resultou em uma modificação praticamente imediata dos textos escolares (publicados em maioria pela própria Espanha) em grande parte da América. Para ele:

Ni la RAE ni ninguna academia de la lengua cuenta con la potestad legal ni la autoridad moral para aprobar, rechazar, censurar ni imponer absolutamente nada. [...] Es difícil subestimar la desfachatez de esta manobra. Es lo mismo que tratar de extirpar los vocablos "porotos", "frijoles" y "caraotas" del vocabulario de distintos países americanos. ¿Con qué derecho!? (SADOWSKY apud ORTIZ, 2017, p. 3)

Em referência, ainda, ao Instituto Cervantes, Scott comenta que, longe de ser uma organização benéfica, trata-se de um organismo do Ministério de Relações Exteriores da Espanha, que deixa claro seu papel de expandir o poder brando espanhol em benefício próprio:

Esta entidad ha establecido centros a lo largo del mundo donde se dan clases de castellano... en su versión peninsular, obviamente. Como resultado, se pueden presenciar situaciones tan absurdas como brasileños que van a trabajar a Argentina y ique tratan a la gente de "vosotros"! O sea, de nuevo, España atenta contra la diversidad de la lengua, y hace negocio al mismo tiempo (SADOWSKY apud ORTIZ, 2017, p. 4).

O posicionamento de Scott Sadowsky é endossado por Ortíz quando faz considerações afirmando:

Sostener que existe una forma correcta de hablar se debe a motivos de dominación que nos hacen creer falsamente que existen hablas de mayor prestigio. España continúa y continuará perpetuando el colonialismo lingüístico en América a través de distintas instituciones. Por tanto, es nuestro deber cuestionarnos estas ideas (ORTIZ, 2017, p.4).

A assinatura do Manifesto pôs em pauta na América Latina o imperialismo linguístico e cultural, patrocinado pelas mesmas empresas espanholas que se beneficiaram da onda de privatizações ocorridas nos anos 90. Os assinantes defendiam, ainda, a criação de um "Instituto Borges" (em referência ao escritor Jorge Luis Borges), destinado a sensibilizar quanto à nãorestrição das dimensões política e cultural da língua e que se projetasse sobre as grandes lutas contemporâneas que envolvem a hegemonização linguística e a democratização da linguagem. Todas essas manifestações, obviamente, não ganharam repercussão na Espanha, que optou por 
ignorar tudo que fez oposição às políticas e práticas da RAE, do Instituto Cervantes e dos órgãos subordinados a eles, mas não foi suficiente para aplacar o movimento.

O surgimento de entidades de articulação política como Mercosul, ALCA e Unasur, nesse mesmo período, abria a possibilidade de considerar a questão da língua a nível regional, forjando uma aliança entre países. Essa unidade política causou grandes desconfortos no continente europeu, que se apressou em tentar mostrar ao mundo a unidade existente entre Espanha e suas ex-colônias, iniciando forte campanha pela construção de uma identidade "iberoamericana", tentando fortalecer a ideologia de pertencimento dos latino-americanos à "pátria-mãe" Espanha. O slogan "limpia, fija y da esplendor" deu lugar a "única y diversa”, tentando mostrar que, apesar de unificado, o espanhol respeitava a diversidade linguística, fato que caiu por terra quando a RAE cria o Diccionario Panhispanico de Dudas e considera "vulgar" ou "incorreta" uma grande maioria de palavras de uso americano. A língua, assim desprovida de sua diversidade étnica, fica comprometida em sua característica instrumental, tornando-se em parte um dispositivo técnico de penetração econômica e, por outra, uma forma de colonização e propagação de culturas dominantes.

No Brasil, nesse mesmo contexto e ano, a Academia Brasileira de Letras senta à mesa novamente com a Academia de Ciências de Lisboa na tentativa de (mais uma vez) concretizar a tão desejada unidade linguística. Desta vez, todos os países luso falantes são chamados e, desse encontro, resulta o Acordo Ortográfico de 1990 (AO90), com o objetivo de promover a equiparação da gramática portuguesa em todos os países que adotaram a língua, porém, novamente o acordo enfrenta oposições contundentes dentro e fora do país.

Para os opositores portugueses, o AO90 está sendo visto como retrocesso linguístico, não porque promova um regresso a antigas regras, mas porque sua proposta é brasileira. Por esse motivo, as críticas afirmam que o Brasil está querendo se impor sobre Portugal para facilitar sua penetração e influência nos países de expressão portuguesa, ou seja, o AO90 estaria servindo a interesses geopolíticos e empresariais brasileiros.

Nessa linha opositora, a jornalista e escritora portuguesa, Isabel A. Ferreira, tece diversas críticas ao AO90, principalmente enfatizando que está se optando por uma grafia pertencente "a uma ex-colônia", o que seria para ela um "grave erro de fraqueza moral" cujos interesses são "formas de facilitar para os brasileiros mediocrizando a língua"? E ressalta: "A língua oficial de Portugal é o português [...] Não a queremos sul-americanizada".

Discursos como este chamam a atenção por estarem carregados de um colonialismo que, certamente, também inunda (em sentido contrário) muitos escritores e gramáticos brasileiros que se opõem ao AO90. Fica evidente que é normal aos portugueses a imposição e realização de mudanças linguísticas ao Brasil sem ter em conta suas singularidades - o que vinha sendo feito em todos os acordos anteriores - mas jamais o inverso, pois, (nas palavras da própria jornalista) isso é o "impensável e vergonhoso ensino de uma língua assente numa grafia estrangeira, que não o identifica (Portugal) como uma nação independente”. O que é o Brasil, então, a partir de

\footnotetext{
7 Blog "O lugar da língua portuguesa" - Texto: "É inadmissível que uma professora marque como 'erro', os vocábulos que uma aluna do $5^{\circ}$ ano de escolaridade escreve correCtamente em sua Língua Materna” https://olugardalinguaportuguesa.blogs.sapo.pt/

${ }^{8}$ Trecho extraído do texto "Vamos falar do AO90 em português?" - Blog "O lugar da língua portuguesa"
} 
tal afirmação?

Apesar do uso de justificativas legais para recusar-se a implantar o AO90, a resistência portuguesa também possui um cunho político, muito mais focado no ideário (ainda vigente) de um Portugal colonizador, do que nas diferenças gramaticais, como afirma Tânia Rezende ao explicar que "Portugal colonizou o Brasil; a língua veio de lá pra cá. Então, se a proposta de mudança vai daqui pra lá, simbolicamente a mudança é muito forte" ${ }^{9}$. Ainda segundo ela, Brasil e Portugal possuem preferências sintáticas diferentes que, embora não impeçam a comunicação, indicam que o português brasileiro é uma outra língua.

Resistência similar ao AO90 é enfrentada por Angola e Moçambique, que se recusam a ratificar o acordo sem que haja alterações que garantam suas diversidades linguísticas, já que são países que não possuem apenas o português como língua oficial.

Seja qual for o rumo tomado, a assinatura do AO90 trouxe à tona o ideário colonialista que se encontrava encoberto pelos discursos da globalização. Dentro de um contexto em que os debates sobre decolonialidade emergem e ganham força em todos os países americanos, retomar as discussões em torno da colonialidade presente na língua pode significar a retomada das reivindicações de uma autonomia linguística e o emergir de uma língua híbrida dentre as mais faladas do mundo.

Brandão (2009) faz críticas contundentes à educação que serve interesses de dominação, determinando incluídos e excluídos e escolhendo conteúdos que objetivam a preservação de um sistema opressor. Esse mesmo pensamento é compartilhado por Freire ao considerar:

a necessidade de compreender-se que a linguagem envolve questões ideológicas e de poder. 'Se há um 'padrão culto' é porque há outro considerado inculto. Quem perfilou o inculto como tal?" (FREIRE, 1993, p. 96).

E complementado pelo conceito de que:

Para que haja multiculturalidade é necessária a "unidade na diversidade”, para que os vários grupos oprimidos possam tornar-se mais efetivos em sua luta coletiva contra todas as formas de opressão. Sem a unidade na diversidade não há como as minorias lutarem pelos seus direitos e superarem as suas situações de opressões (FREIRE apud OLIVEIRA, 2011, p. 121).

Para o autor, a "[...] busca na unidade na diferença, a luta por ela, como processo, significa já o começo da criação da multiculturalidade [...]” (FREIRE, 1993, p. 157). Assim, falar do ensino de uma língua, pressupõe - inevitavelmente - se falar da cultura e da história que a constituem e lhe formam a identidade.

Assim, é preciso romper com o eurocentrismo e o etnocentrismo do ensino e do saber e com a ideia equivocada de homogeneidade idiomática, buscando metodologias, práticas e estratégias que reafirmem as lutas históricas por independência e autonomia dos povos e, ao mesmo tempo, reafirmem nossas identidades plurais em torno da pluralidade de nossas "muitas línguas" (grifo nosso) americanas.

\footnotetext{
${ }^{9}$ Doutora em estudos linguístico e professora da UFG (entrevista do texto "O lugar da língua portuguesa”).
} 


\section{Considerações Finais}

O que é falar errado? A quem corresponde classificar a fala de um povo? Quando os espanhóis chegaram às Américas disseram em cartas enviadas ao rei espanhol "os nativos precisam ser ensinados a falar”. Essa frase parece ter tomado, desde então, proporções de verdade absoluta e inquestionável: os países americanos, para os "colonizadores" europeus, parecem continuar não sabendo falar.

Ao longo de décadas Espanha e Portugal tem se empenhado em ditar as regras gramaticais e orais aos idiomas falados nos países latinos, ignorando propositalmente a diversidade cultural que veio recriando essas línguas e amparando-se na ideia de multiculturalismo que invisibiliza as raízes dos conflitos culturais existentes. Instituições como o Instituto Cervantes e as Academias implantadas por ele nos países latinos - vinculados à Real Academia Espanhola (RAE) - e a Academia Brasileira de Letras se tornaram a "mão de ferro" de Portugal e Espanha nas escolas e cursos de idiomas americanos.

Ao criarem seus dicionários gramaticais, essas instituições passaram a classificar como "erros" ou "formas vulgares" da língua palavras incorporadas e utilizadas nos países americanos. A partir do momento em que uma forma de comunicação é determinada como culta, outra passa a ser excluída, invisibilizada e silenciada, corroborando o que Walsh (2009) chama de "colonialidade do poder" e "colonialidade do saber".

Entendendo a língua como um aspecto cultural e identitário dos povos, percebemos que as práticas colonizadoras permanecem ativas na relação entre Portugal e Espanha e suas excolônias, através da língua, delimitando não apenas a forma culta da fala, mas o lugar das raças, da racialização e do racismo que caracterizaram a dominação europeia sobre os povos ameríndios e excluindo aqueles que se interponham, com suas diferenças, aos objetivos europeus de obtenção de uma língua única e homogênea.

O conceito de decolonialidade que vem sendo discutido mundialmente, tem criado um contexto de reflexão a respeito das práticas de dominação que ainda vigoram nas sociedades americanas e tensiona sobre a importância de serem adotadas práticas pedagógicas que estabeleçam o fortalecimento de resistências, direcionando para uma decolonialidade idiomática residente em profissionais que não apenas conheçam as regras gramaticais e os conteúdos, mas que sejam conhecedores da diversidade cultural, histórica e linguística dos povos americanos e que tenha suas metodologias e estratégias, igualmente, voltadas para a libertação e humanização dos sujeitos sociais, para o fortalecimento das lutas travadas no campo das diversidades e para a análise das origens de nossas (re)colonialidades.

\section{Referências}

BARTHES, R. Aula inaugural da cadeira de Semiologia Literária do Colégio de França, pronunciada dia 07 de janeiro de 1977. Tradução de Leyla Perrone-Moisés. São Paulo: Cultrix, 1978.

BRANDÃO, C. R. Cultura rebelde: escritos sobre a educação popular ontem e agora. São Paulo: 
Editora e Livraria Instituto Paulo Freire, 2009.

ECHEVARRIA, F.; STURZA, E. R. A influência dos percursos percorridos pela língua no Brasil na produção de instrumentos linguísticos. Linguagens $\mathbb{E}$ Cidadania, v. 17, jan./dez., 2015. Disponível em: <https://periodicos.ufsm.br/LeC/article/view/25509/14896> Acessado em: 01/01/20

FREIRE, P. Pedagogia da esperança: um reencontro com a pedagogia do oprimido. 2. ed. Rio de Janeiro: Paz e Terra, 1993

GARCIA, E. F. O projeto pombalino de imposição da língua portuguesa aos índios e sua aplicação na América Meridional. Revista Tempo, Rio de Janeiro, 2007, vol. 23, pp. 23- 38. Disponível em: <http://www.scielo.br/pdf/tem/v12n23/v12n23a03> Acessado em: 27/12/19.

GUIMARÃES, E. A língua portuguesa no Brasil. Revista Ciência e Cultura, vol. 57, no. 2, São Paulo abril/junho 2005. Disponível em: <cienciaecultura.bvs.br/scielo.php?script=sci_arttext\&pid=S0009-67252005000200015> Acessada em: 26/12/19.

LAGARES, X. C. O espaço político da língua espanhola no mundo. Trab. Linguist. apl. [online]. 2013, vol.52, n.2, pp.385-408. Disponível em: $<$ http://www.scielo.br/scielo.php?pid=S010318132013000200009\& script=sci_abstract\& $\mathrm{t}$ lng=pt $>$ Acessado em: 21/12/18.

MANIFIESTO: "Por una soberanía idiomática". Disponível em: <http://soberaniaidiomatica.blogspot.com.br/2013/09/por-una-soberania-idiomatica.html>. Acesso em 12 de dezembro de 2018.

MEDEIROS, A. A. D. História da língua no Brasil (Art.). Site Ã. DCA-UFRN, p. 3.3.a., 2006. Disponível em: <http://www.linguaportuguesa.ufrn.br/pt_3.3.a.php> Acessado em: 21/12/2019.

OLIVEIRA, I. A. Cultura e interculturalidade na Educação Popular de Paulo Freire. EccoS Rev. Cient., São Paulo, n. 25, pp. 109-124, jan./jun. 2011.

OliveIRA, R. G. O tratamento da variação no Dicionário Pan- hispânico de Dúvidas (Dissertação). Programa de Pós-graduação em Letras neolatinas da UFRJ. Rio de Janeiro: UFRJ / Faculdade de Letras, 2010. Disponível em:

<https://www.teses.usp.br/teses/disponiveis/8/.../2014_DanielaIonaBrianezi_VCorr.pdf> Acessado em: 21/12/18

ORLANDI, E. P. A língua brasileira. Ciência e Cultura, São Paulo, v. 57, n. 2, 2005. Disponível em: $\quad<$ http://cienciaecultura.bvs.br/scielo.php?script=sci_arttext\&pid=S0009. 67252005000200016> Acessado em: 28/12/2019.

ORTÍZ, J.. El invisible colonialismo de la lengua. Revista La Marraqueta, de 12/10/17. Disponível em: <http://revistalamarraqueta.cl/articulos/invisible-colonialismo-la-lengua/> Acessado em: 15/03/19.

PALHARES, A. C. M. H. Língua, cultura, educação e colonialidade: reflexões sobre o ensinoaprendizagem de línguas em uma perspectiva pós-colonial. Revista Interface de saberes, vol. 12, n. 1, 2012. Disponível em: <https://interfacesdesaberes.faficape.edu.br/index.php/import1/article/view/158> Acessado em: 01/01/20.

PASSINATTO, R. Políticas linguísticas no Brasil: da dominação dos nativos ao silenciamento 
dos imigrantes. Domínios de Lingu@gem, Instituto de Letras e Linguística - UFU, v. 13, n. 1, pp. 149-174, 3 fev. 2019. Disponível em: <http://www.seer.ufu.br/index.php/dominiosdelinguagem/article/view/42006> Acessado em: $01 / 01 / 20$

WALSH, C. Interculturalidade crítica e Pedagogia decolonial: in-surgir, re-existir e re-viver. In: CANDAU, Vera Maria (orgs.). Multiculturalismo: diferenças culturais e práticas pedagógicas. Petrópolis, RJ: Vozes, 2009.

Recebido em: 20/01/2020

Aceito em: 16/02/2020 